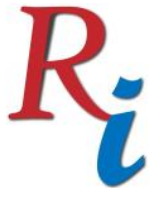

Asia Proceedings of Social Sciences

(APSS)

www.readersinsight.net/APSS

\title{
ATTITUDE OF NIGERIAN PRIMARY SCHOOL STUDENTS TOWARD MATHEMATICS SUBJECT
}

\author{
Fatima Daudu Suleiman
}

School of Education

Universiti Teknologi Malaysia

Malaysia

amietaf@gmail.com

\section{Mohd Rustam Mohd Rameli*}

School of Education

Universiti Teknologi Malaysia

Malaysia

mrustam2@utm.my

\section{Muhammad Ado}

Departement of Physics

Bayero University, Kano

Nigeria

adobaffa@gmail.com

*Corrosponding author's Email: mrustam2@utm.my

Peer-review under responsibility of 4th Asia International Multidisciplinary Conference 2020 Scientific Committee http://connectingasia.org/scientific-committee/

(C) 2020 Published by Readers Insight Publisher, lat 306 Savoy Residencia, Block 3 F11/1,44000 Islamabad. Pakistan,

editor@ readersinsight.net

This is an open access article under the CC BY-NC-ND license (http://creativecommons.org/licenses/by-nc-nd/4.0/). 


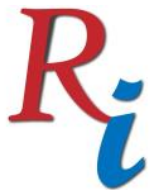

\section{Asia Proceedings of Social Sciences (APSS) \\ www.readersinsight.net/APSS}

\section{A b s t r a c t}

Attitude is an affective variable that can affect the academic life of students significantly. In Nigeria, attitude in mathematics is among the factors influencing performance in maths subject, especially among primary school students. This study aimed at identifying factors that indicate the student's negative attitude in maths subject. The population of the study is 1,626 from 6 selected primary schools in Nasarawa Local Government Area of Kano, Nigeria. A sample of 384 respondents were selected using the Krejcie and Morgan table. A Math Attitude questionnaire (MAQ) was completed by the respondents which measure the students affect, behaviour and cognitive aspects. The data collected were analysed using the statistical package for social science (SPSS). The results show that the respondents are experiencing a negative attitude in maths subject. It is recommended that parents and teachers are required to provide some supportive measures for changing the student's attitude. If a negative attitude among students is not addressed, the career of students will be very limited and their maths performance will be relatively poor as well.

\section{Rese a r ch H igh I ight s}

Determined the level of attitude in maths among primary school students.

Attitude in mathematics is very important in learning and teaching.

Mathematics attitude questionnaire (MAQ) is adapted and used for collecting data.

\section{Research Objectives}

1 To determine the level of attitude in mathematics among primary school children in Nasarwa Local Government Kano Nigeria.

2 To determine factors responsible for negative attitude in mathematics among them Significance

Attitude has been expressed as an organization of beliefs and behavioural tendencies which an individual hold towards some certain groups, objects, symbols, or events (Hogg and Vaughan, 2010; Ntibi and Edoho, 2017). Consequently, student's attitude can be positive or negative, dislike or like, unfavourable or favourable degree of affect which is associated with a certain subject. Attitude can also be seen as the feeling and belief that students have toward math subject. In a nutshell, attitude can be seen as how a student feels about his performance in the math subject and their confidence level in solving math's problem and also their belief on the importance of math's knowledge to them (Adediwura and Tayo, 2007; Chaudhary et al., 2019; Lemu and Getahun, 2019). 


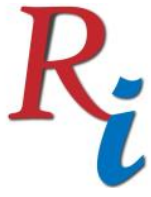

\section{Asia Proceedings of Social Sciences}

(APSS)

www.readersinsight.net/APSS

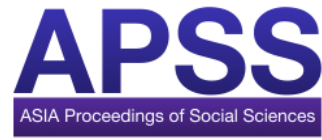

Considering the significance of attitude toward learning mathematics, it is the aim of this study to identify the level of attitude as well as factors that are responsible for negative attitude among primary school students in Nasarawa Local Government Kano, Nigeria. The findings of this study will be beneficial to parents and teachers in such a way that they will be aware of the risk factors associated with negative attitude so that they guide students/children toward developing a positive attitude in learning mathematics. The study is also important for the students by providing a better and clear understanding of the factors associated with their negative attitude in learning mathematics.

\section{Methodology}

The study is a cross-sectional and a quantitative research approach employed to determine the level of attitude in maths among 384 Nigerian primary school students (sample size). Mathematics attitude questionnaire (MAQ) is adapted and used for collecting data. MAQ is designed to measure the attitude of students toward learning maths subject and it comprised 29 items and three sub-constructs which include affective, behaviour and cognitive aspects (Mazana et al., 2018). The study sample comprises of primary 5 students from 6 sellected schools in Nasarawa L.G.A which are chosen by a stratified sampling method.

\section{Results}

MAQ is used to determine the level of attitude in maths among primary school students in Nasarawa. The first factor is titled "Affective", it is an emotional component which measures student's feelings and emotions associated with the students' attitude toward learning mathematics, this entails the student's enjoyment and self-confidence in learning the maths subject. This factor indicates a mean of 2.73 which shows a moderate level of attitude among the students.

Factor two titled "behaviour" which comprise of all sort of actions and attitude displayed by the learner toward learning math's subject, and it shows the extent to which the students can or cannot perform a giving mathematical task by himself. This factor indicates a mean score of 2.88 which indicate a moderate level of the behaviour in attitude toward math's among the primary school students.

Factor three is titled the "cognitive component". The cognitive component is an aspect that deals with the knowledge and information a student is able to know about his ability in solving math's as well as the usefulness of the math subject, this factor recorded a mean score of 3.32 which indicate a high level of attitude in math's among the primary school students. 


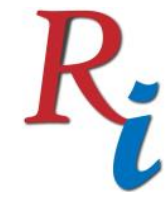

\section{Asia Proceedings of Social Sciences (APSS) \\ www.readersinsight.net/APSS}

\section{Findings}

The descriptive statistics for this study indicates that the overall mean of attitude is 2.98 with standard deviation (SD) of 0.37 which shows the students attitude toward mathematics is moderate. Attitude in mathematics is very important in learning and teaching processes and it can affect the student's maths achievement. The findings of this study collaborate with an extensive literature in Nigeria that found a moderate attitude among the students (Jegede and Olojede, 2019), he explained that a negative attitude in maths among students can lead to a frequent poor math performance and difficulties whenever come across some mathematical task. The findings is also in line with the sstudy of (Garba and Musa, 2019) that found that student's attitude is significantly affected by the student's achievement and performance.

\section{References}

Adediwura, A.A., Tayo, B., 2007. Perception of teachers' knowledge, attitude and teaching skills as predictor of academic performance in Nigerian secondary schools. Educ. Res. Rev. 2, 165-171.

Chaudhary, A.Q., Malik, M., Rafiq, N., 2019. Attitude of Students towards Learning Mathematics at Elementary Level. J. Elem. Educ. 29, 109-120.

Garba, A., Musa, D.C., 2019. Attitude to mathematics, study habit and academic performance of selected secondary schools in makurdi metropolis. J. Adv. Res. Math. Stat. 2443.

Hogg, M.A., Vaughan, G.M., 2010. Essentials of Social Psychology., Psychological Bulletin. https://doi.org/10.1037/h0064341

Jegede, E.O., Olojede, A.I., 2019. Teachers 'Workload and Students 'Attitude toward Mathematics in Senior Secondary Schools in Kogi State. J. SCIECNCE Technol. Educ. 7, 334-339.

Lemu, B.G., Getahun, T., 2019. Determinants of Students' Academic Achievement and Attitude in Mathematics Subject: A Case Study at Gindeberet Preparatory School. Educ. J. 8, 144. https://doi.org/10.11648/j.edu.20190804.13

Mazana, M.Y., Montero, C.S., Casmir, R.O., 2018. Investigating Students' Attitude towards Learning Mathematics. Int. Electron. J. Math. Educ. 14, 207-231. https://doi.org/10.29333/iejme/3997

Ntibi, J.E.-E., Edoho, E.A., 2017. Influence of School Location on Students Attitude Towards. Br. J. Educ. 5, 76-85. 